ISSN 0258-7122 (Print), 2408-8293 (Online)

Bangladesh J. Agril. Res. 41(2): 259-271, June 2016

\title{
VARIABILITY AND PATH CO-EFFICIENT FOR YIELD AND YIELD COMPONENTS IN RICE
}

\author{
SK. SAMEERA ${ }^{1}$, T. SRINIVAS ${ }^{2}$, A. P. RAJESH ${ }^{3}$ \\ V. JAYALAKSHMI ${ }^{4}$ AND P. J. NIRMALA ${ }^{5}$
}

\begin{abstract}
Twenty five rice varieties were evaluated for their variability with regard to yield and yield components. Estimates of heritability and genetic advance as per cent mean were also obtained for the above traits. In addition, studies on character associations and path co-efficients were also undertaken. The results revealed high variability, heritability and genetic advance as per cent mean for productive tillers per plant, number of tillers per plant, number of grains per panicle and number of filled grains per panicle, while days to maturity was recorded with high heritability coupled with low genetic advance as per cent of mean. Further, yield was observed to be positively associated with number of tillers per plant, productive tillers per plant, number of grains per panicle and number of filled grains per panicle. Among these, number of tillers per plant, productive tillers per plant and number of filled grains per panicle were noticed to exert high direct effects on grain yield per plant. High indirect effects of most of the traits were noticed mostly through productive tillers per plant indicating importance of the trait as selection criteria in crop yield improvement programmes.
\end{abstract}

Keywords: Correlation, grain yield, heritability, path analysis, rice, variability, yield components.

\section{Introduction}

Rice (Oryza sativa L.) is the world's most staple food for more than half the world's population. Crop yield improvement is of prime importance to meet its rising demand owing to constant increase in population. In this context, assessment of variability in the crop for grain yield and yield attributes is the essential for successful exploitation and improvement of yield through breeding. Further, grain yield depends on various component characters and knowledge of correlations among yield component traits and yield is of great importance in selection of elite genotypes for breeding programmes. Path analysis also helps in determining the direct and indirect causes of association and formulation of effective breeding strategies for development of better genotypes. In this direction, the present investigation was undertaken to assess the magnitude of variability and character associations, in addition to direct and indirect effects among yield and yield component characters in 25 different rice varieties.

\footnotetext{
${ }^{1-5}$ Department of Genetics and Plant Breeding, Agricultural College, Mahanandi-518 502, Andhra Pradesh, India.
} 


\section{Materials and Method}

Experimental materials for the present investigation comprised of 25 rice varieties obtained from different rice research stations of the erstwhile Andhra Pradesh state of India, namely, Bapatla, Jagtial, Nandyal, Nellore, Rajendranagar, Ragolu and Rudrur of Acharya N. G. Ranga Agricultural University. These were sown during kharif 2013 in a randomized block design with three replications. Thirty day-old seedlings of each variety were transplanted in four-row plots of $4.0 \mathrm{~m}$ length, at a spacing of $20 \mathrm{~cm}$ between rows and $15 \mathrm{~cm}$ between plants within the row. All recommended practices were followed to raise a healthy crop and observations were recorded for grain yield and yield component characters. The observations on plant height, number of tillers per plant, productive tillers per plant, panicle length, number of grains per panicle, number of ill-filled grains per panicle, number of filled grains per panicle, test weight, harvest index and grain yield per plant were recorded from five randomly selected plants for each entry in each replication. However, observations on days to 50 per cent flowering and days to maturity were recorded on plot basis. Data thus obtained were subjected to standard statistical procedures proposed by Panse and Sukhatme (1961). The variability parameters, namely, genotypic and phenotypic coefficient of variation were calculated as per the formulae proposed by Burton and Devane (1952) and categorized as per the procedure suggested by Sivasubramanian and Madhavamenon (1973). Estimates of heritability in broad sense $\left[\mathrm{h}^{2}\right.$ (b)] and genetic advance were calculated by the formulae given by Lush (1940) and Johnson et al. (1955), respectively. Categorization was done as per the procedure outlined by Johnson et al. (1955). Further, genotypic and phenotypic correlation coefficients were calculated using the method detailed by Johnson et al. (1955), while the direct and indirect contribution of different yield component characters on grain yield per plant was estimated by path co-efficient analysis suggested by Wright (1921).

\section{Results and Discussion}

Analysis of variance (ANOVA) for yield and yield component characters studied is presented in Table 1 . The results revealed highly significant mean squares due to varieties for all traits, indicating the existence of sufficient variation among the varieties for yield and yield component characters studied in the present investigation, and a scope for effective selection.

Information on mean, range, phenotypic co-efficient of variation (PCV), genotypic co-efficient of variation (GCV), heritability, genetic advance and genetic advance as per cent mean for yield and yield component traits are furnished in Table 2. A perusal of these results revealed maximum range of variability for number of grains per panicle followed by number of filled grains per panicle. Higher phenotypic variance and co-efficient of variation were in 
general recorded for all the traits studied in the present investigation, compared to genotypic variance and co-efficient of variation, indicating the influence of environment. Similar findings were reported earlier by Mamta Singh et al. (2007). However, the high (>20\%) phenotypic variance (days to 50 per cent flowering, days to maturity, plant height, number of grains per panicle, number of filled grains per panicle and harvest index) and co-efficient of variation (number of tillers per plant, productive tillers per plant, number of grains per panicle and number of filled grains per panicle) observed in the present investigation was noticed to be essentially associated with high genotypic variance and co-efficient of variation of the particular trait, indicating the minimal influence of environment and presence of high genetic variability for these traits in the experimental material. Hence, selection on the basis of phenotype can also be effective for improvement of these traits. Similar results were reported earlier by Babu et al. (2012). Further, the high (>20\%) estimates of genotypic and phenotypic co-efficient of variation recorded for productive tillers per plant, number of tillers per plant, number of grains per panicle and number of filled grains per panicle in the present study are in conformity with the findings of Bekele et al. (2013) for productive tillers per plant; Prasad et al. (2013) for number of tillers per plant; Deepa Sankar et al. (2006) for grains per panicle and Srinivas et al. (2004) for filled grains per panicle. However, moderate (10-20\%) genotypic and phenotypic variance estimates were recorded in the present study for 1000 seed weight, while grain yield per plant, number of ill-filled grains per panicle and harvest index had recorded moderate (10-20\%) estimates of genotypic and phenotypic co-efficient of variation. These results are in conformity with the findings of Das et al. (2005) for grain yield per plant and Dhanwani et al. (2013) for harvest index. In contrast, low $(<10 \%)$ estimates of genotypic and phenotypic variance and co-efficient of variation were observed in the present study for number of tillers, followed by productive tillers per plant, panicle length, number of ill-filled grains per panicle and grain yield per plant, while days to 50 per cent flowering, days to maturity, plant height and panicle length had low $(<10 \%)$ genotypic and phenotypic coefficient of variation, indicating low variability for these characters in the present experimental material and therefore little scope for improvement of these traits. Similar findings were reported earlier by Adilakshmi and Girijarani (2012) for days to 50 per cent flowering; Satish et al. (2003) for plant height and Idris et al. (2013) for days to maturity.

High ( $>60 \%)$ estimates of heritability were recorded for all characters studied in the present investigation (Table 2). Maximum heritability was recorded for number of filled grains per panicle, followed by number of grains per panicle, productive tillers per plant, days to maturity, number of tillers per plant, harvest index, 1000 seed weight, days to 50 per cent flowering, number of ill-filled 
grains per panicle, panicle length, grain yield per plant and plant height. These results are in conformity with the reports of Idris et al. (2013) for number of filled grains per panicle, days to maturity, 1000 seed weight, panicle length and plant height; Bisne et al. (2009) for productive tillers per plant; Singh et al. (2012) for number of grains per panicle; Idris et al. (2013) for harvest index; Dhanwani et al. (2013) for days to 50 per cent flowering; Babu et al. (2012) for number of ill-filled grains per panicle and Kundu et al. (2008) for grain yield per plant.

A perusal of the results on genetic advance revealed high $(>20 \%)$ values for number of grains per panicle and number of filled grains per panicle. The estimates of genetic advance as per cent mean was also high (>20\%) for productive tillers per plant, followed by number of tillers per plant, number of grains per panicle, number of filled grains per panicle, 1000 seed weight, grain yield per plant, number of ill-filled grains per panicle and harvest index. These results are in conformity with the findings of Parvathi et al. (2011) for productive tillers per plant and number of tillers per plant; Idris et al. (2013) for number of grains per panicle; Babu et al. (2012) and Dhanwani et al. (2013) for number of filled grains per panicle and number of ill-filled grains per panicle; Dhanwani et al. (2013) for 1000 seed weight and grain yield per plant and Mamta singh et al. (2007) for harvest index. In contrast, moderate (10-20\%) estimates of genetic advance were noticed in the present study for days to 50 per cent flowering, days to maturity and plant height. Moderate (10-20\%) genetic advance as per cent mean were also recorded for panicle length, days to 50 per cent flowering and plant height. Similar results were reported by Parvathi et al. (2011) for panicle length and days to 50 per cent flowering and Babu et al. (2012) for plant height. Further, low $(<10 \%)$ estimates of genetic advance were recorded in the present investigation for number of tillers per plant, productive tillers per plant, panicle length, number of ill-filled grains per panicle, 1000 seed weight, harvest index and grain yield per plant. Low $(<10 \%)$ estimates of genetic advance as per cent mean were also noticed for days to maturity in the present investigation. These results are in conformity with the findings of Seyoum et al. (2012).

High heritability coupled with high genetic advance as per cent mean was recorded for all the characters under study, except days to 50 per cent flowering, days to maturity, plant height and panicle length indicating that the high heritability observed is due to additive gene effects and selection may be effective for these characters. Similar observations were reported by Bekele et al. (2013) for tillers per plant; productive tillers per plant and harvest index; Idris et al. (2013) for number of grains per panicle; Dhanwani et al. (2013) for number of filled grains per panicle and number of ill-filled grains per panicle and 


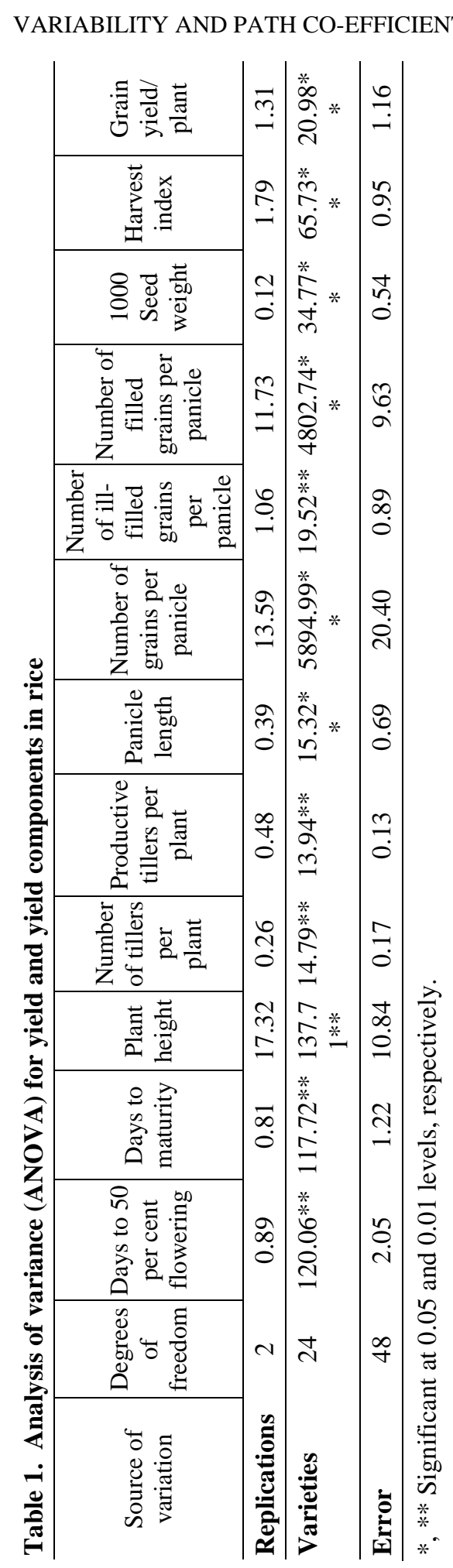




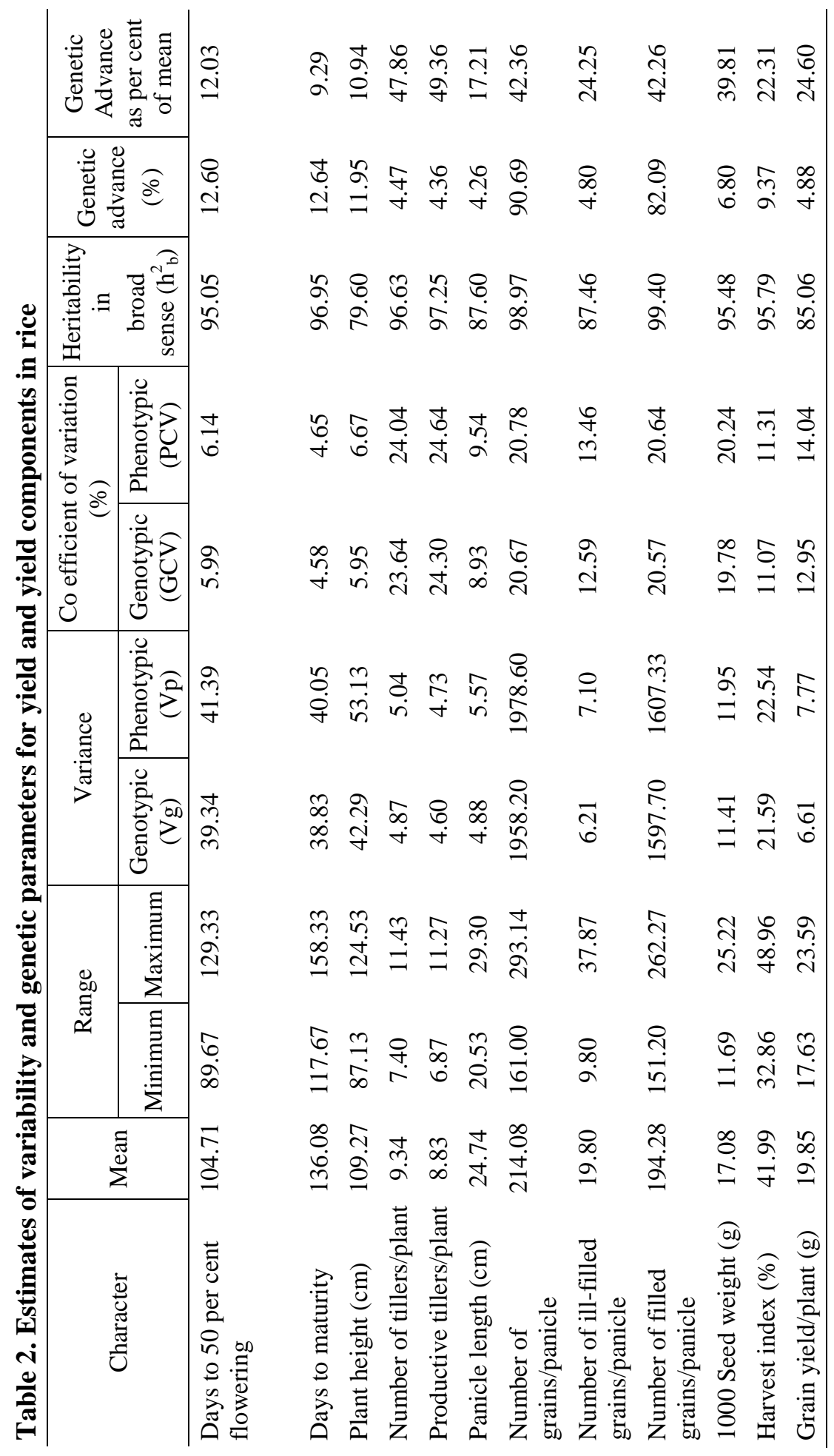


Adilakshmi and Girijarani (2012) for 1000 seed weight. On the contrary, high heritability coupled with moderate genetic advance as per cent mean was observed for plant height and panicle length indicating the role of both additive and non-additive gene effects for control of the characters. The results are in conformity with the reports of Seyoum et al. (2012) for plant height. However, for days to maturity, high heritability coupled with low genetic advance as per cent of mean was noticed in the present investigation, which was similar to the findings of Singh et al. (2012).

Burton and Devane (1952) had reported that information on genetic variation along with heritability and genetic advance estimates gave a better idea about the efficiency of selection. In the present study, high GCV and PCV coupled with high heritability and high genetic advance as per cent mean were observed for productive tillers per plant followed by number of tillers per plant, number of grains per panicle and number of filled grains per panicle, indicating the preponderance of additive gene action and scope for their improvement through selection. Similar results were reported earlier by Selvaraj et al. (2011) for productive tillers per plant.

Yield is a complex character and is the end product of multiplicative interaction between various yield components (Grafius, 1956). Information on the nature and extent of association among yield and yield component characters is therefore essential for systematic crop improvement. Further, the study of genetic correlations also gives an idea about the extent to which the characters are under the control of genes and this kind of analysis could help the breeder to design his selection for effective crop improvement. Correlations (phenotypic and genotypic) of yield and yield component characters in the present investigation are presented in Table 3. A perusal of these results, in general, revealed phenotypic and genotypic correlations of similar direction and significance. However, genotypic correlations had recorded a higher magnitude, compared to phenotypic correlations, indicating the masking effect of environment (Johnson et al., 1955). Further, grain yield per plant was observed to be positively and significantly associated with number of tillers per plant, productive tillers per plant, number of grains per panicle and number of filled grains per panicle indicating an increase in grain yield with an increase in these characters. Therefore, priority should be given to these traits, while making selection for yield improvement. The findings are in agreement with the reports of Manikyaminnie et al. (2013) for productive tillers per plant and number of grains per panicle; Sudharani et al. (2013) for number of filled grains per panicle and Idris et al. (2013) for number of tillers per plant. On contrary, non-significant association was noticed for grain yield with days to 50 per cent flowering, days to maturity, plant height, panicle length, number of ill-filled grains per panicle, 1000 seed weight and harvest index. The findings are in consonance with the 
reports of Yadav et al. (2010) for days to 50 per cent flowering, plant height, panicle length; and Panwar and Mashiat Ali (2007) for number of ill-filled grains per panicle.

Studies on inter-character associations for yield components revealed significant and positive association of days to 50 per cent flowering with days to maturity; plant height with panicle length; number of tillers with productive tillers per plant, number of grains per panicle, and number of filled grains per panicle; productive tillers with number of grains per panicle and number of filled grains per panicle; number of grains per panicle with number of ill-filled and filled grains per panicle, indicating a scope for simultaneous improvement of these traits through selection. The results are in agreement with the reports of Singh et al. (2012) for days to 50 per cent flowering with days to maturity, and number of tillers with number of grains per panicle; Manikyminnie et al. (2013) for plant height with panicle length, and productive tillers with number of grains per panicle; and Bekele et al. (2013) for number of tillers with productive tillers per plant; Sudharani et al. (2013) for number of tillers with number of filled grains per panicle; Gopikannan and Ganesh (2013) for productive tillers per plant with number of filled grains per panicle; and Vanisree et al. (2013) for number of grains per panicle with number of filled grains per panicle. However, significant and negative inter-character associations were observed for number of grains per panicle with 1000 seed weight; number of filled grains per panicle with 1000 seed weight; and number of ill-filled grains per panicle with 1000 seed weight probably due to competition for a common possibility, such as nutrient supply. The results are in conformity with the reports of Panwar and Mashiat Ali (2007).

Path co-efficient analysis provides an effective means of finding out the direct and indirect causes of association and presents a critical examination of the specific forces acting to produce a given correlation and also measures the relative importance of each causal factor. Hence, the study of direct and indirect effects of yield components on grain yield per plant from genotypic correlation was undertaken in the present investigation and the results obtained are presented in Table 4. The results revealed high residual effect, indicating that variables studied in the present investigation explained only 48 per cent of the variability in yield and therefore, other attributes besides the characters studied are contributing for grain yield per plant. The results also revealed maximum direct effect of productive tillers per plant followed by number of filled grains per panicle and number of tillers per plant on grain yield per plant. High positive direct effect of productive tillers per plant (Manikyaminnie et al. 2013); number of filled grains per panicle and tillers per plant (Parvathi et al. 2011) on grain yield were also reported earlier. These traits had also exhibited highly significant and strong positive association with grain yield per plant. High direct effects of these traits therefore, appeared to be the main factor for their strong association 


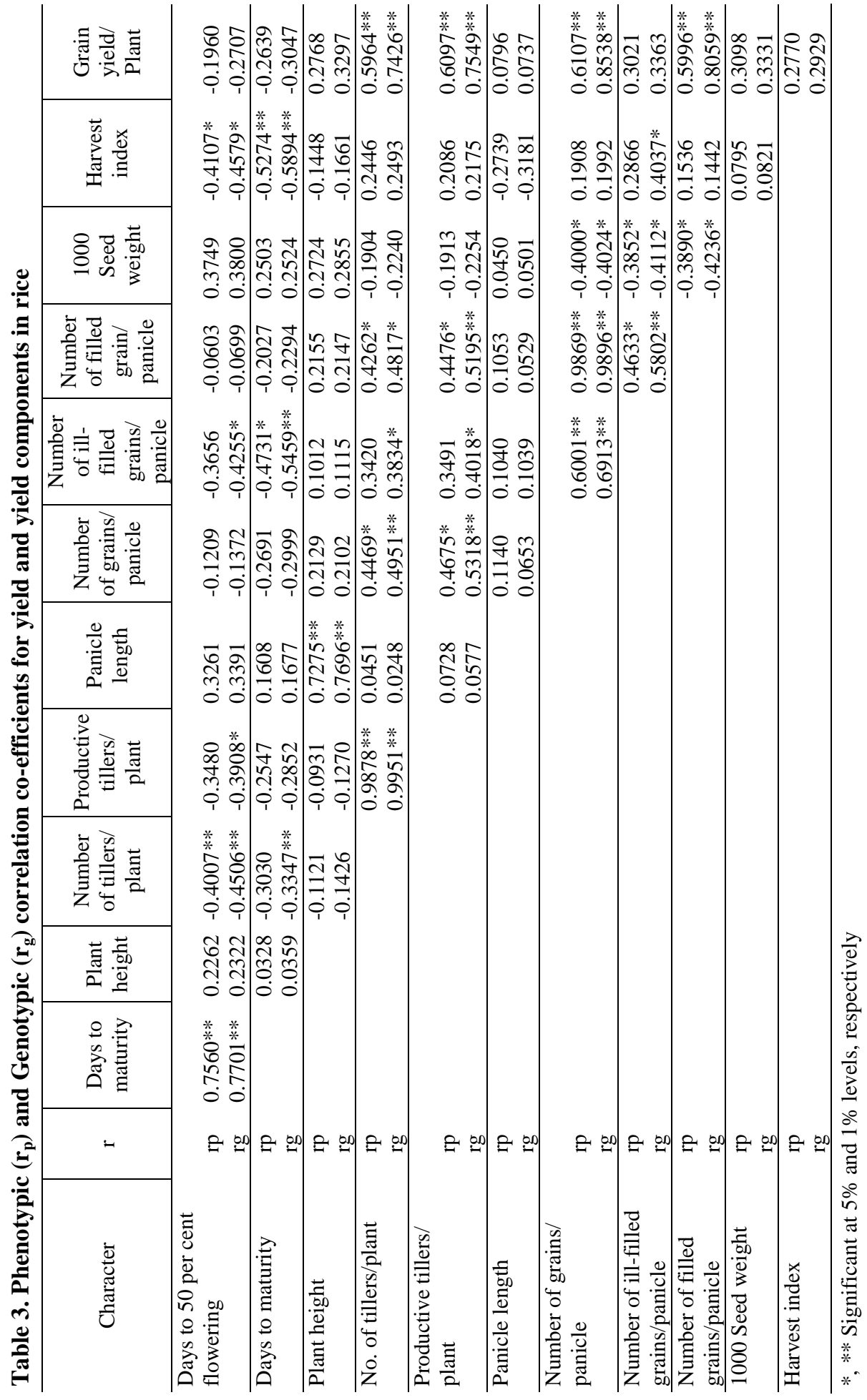


with grain yield per plant. Hence, these traits should be considered as important selection criteria in all rice improvement programmes and direct selection for these traits is recommended for yield improvement. The results are in conformity with the findings of Meena Kumari et al. (2011).

Days to 50 per cent flowering, plant height and 1000 seed weight also had high positive direct effects on grain yield per plant. The results are in consonance with the findings of Seyoum et al. (2012) for days to 50 per cent flowering and Adilakshmi and Girijarani (2012) for plant height and 1000 seed weight. However, its association with grain yield per plant was noticed be non-significant in the present investigation indicating the need for adoption of restricted simultaneous selection model to nullify the undesirable indirect effects and make use of the direct effect (Singh and Kakar, 1977).

High negative direct effects on grain yield per plant was recorded by number of grains per panicle. However its association with grain yield per plant was observed to be highly significant and positive indicating a major role of indirect effects, namely, number of filled grains per panicle, productive tillers per plant and number of ill-filled grains per panicle and hence, a need for simultaneous consideration of these traits in selection programmes along with number of grains per panicle. In addition, days to maturity, panicle length and harvest index also had high negative direct effects on grain yield per plant. The results are in agreement with the reports of Madhavilatha et al. (2005). Association of these traits with grain yield per plant was however, non-significant indicating the indirect effects of these traits on grain yield per plant through other characters. High indirect effects of these traits were noticed mostly through productive tillers per plant indicating importance of the trait as selection criteria. The findings are in conformity with the reports of Manikyaminnie et al. (2013).

A perusal of the results thus emphasized the need for selection based on productive tillers per plant, number of filled grains per panicle and number of tillers per plant for improvement of grain yield in rice.

\section{References}

Adilakshmi, D. and M. Girijarani. 2012. Variability, character association and path analysis in rice under submergence. Crop Res. 44 (1 and 2) : 146-151.

Babu, V. R., K. Shreya, kuldeepsinghdangi, G. Usharani and P. Nagesh. 2012. Genetic variability studies for qualitative and quantitative traits in popular rice (Oryza sativa L.) hybrids of India. International journal of scientific and research publications 2(6): $1-5$.

Bekele, B.D., S. Rakhi, G.K. Naveen, P.J. Kundur and H.E. Shashidhar. 2013. Estimation of genetic variability and correlation studies for grain zinc concentrations and yield related traits in selected rice (Oryza sativa L.) genotypes. Asian J. Expt. Bio. Sci. 4 (3) : 391-397. 
Bisne, R., A.K Sarawgi and S.B. Verulkar. 2009. Study of heritability, genetic advance and variability for yield contributing characters in rice. Bangladesh J. Agril. Res. 34(2); 175-179.

Burton, G.W. and E.H. Devane. 1952. Estimating heritability in tall fescue (Festuca arundinaceae) from replicated clonal material. Agron. J. 45 : 478-481.

Das, R., T.K. Borbora, M.K Sarma and N.K. Sarma. 2005. Genotypic variability for grain yield and flood tolerance in semi deep water rice (Oryza sativa L.) of Assam. Oryza. 42 (4): 313-314.

Deepa Sankar, P., A Sheeba and J. Anbumalarmathi. 2006. Variability and character association studies in rice (Oryza sativa L.). Agricultural Science Digest. 26 (3): 182-184.

Dhanwani, R.K. A.K. Sarwgi, Akash Solanki and Jitendra Kumar Tiwari. 2013. Genetic variability analysis for various yield attributing and quality traits in rice (Oryza sativa L.). The Bioscan 8 (4) : 1403-1407.

Gopikannan, M and S.K. Ganesh. 2013. Inter-relationship and path analysis in rice ( Oryza sativa L.) under sodicity. Ind. J. Sci. and Tech. 6 (9) : 5223-5227.

Grafius, J.E. 1956. Components of yield in oats: a geometrical interpretation. Agron. J. 48: 419-423.

Idris, A.E and K.A. Mohamed. 2013. Estimation of genetic variability and correlation for grain yield components in rice (Oryza sativa L.). Global J. plant Ecophysiology. 3 (1) : 1-6.

Johnson, H. W., H. F Robinson and R.E. Comstock. 1955. Estimation of genetic and environmental variability in soybean. Agron. J. $47: 314-318$.

Kundu, A., B.K. Senapati, A Bakshi and G.S. Mandal. 2008. Genetic variability of panicle characters in tall indica aman rice. Oryza. 45 (4) : 320-323.

Lush, J.L. 1940. Intra-sire correlation and regression of offspring in rams as a method of estimating heritability of characters. Proc. of American Soc. Animal Product. 33 : 292-301.

Madhavilatha, L., M. Reddi sekhar, Y. Suneetha and T. Srinivas. 2005. Genetic variability, correlation and path analysis for yield and quality traits in rice (Oryza sativa L.). Research on crops. 6 (3): 527-534.

Mamta Singh, K Kumar and R.P. Singh. 2007. Study of co-efficient of variation, heritability and genetic advance in hybrid rice. Oryza. 44 (1) : 160-162.

Manikyaminnie, C., T Dayakar Reddy and Ch. Surendra Raju. 2013. Correlation and path analysis for yield and its components in rice (Oryza sativa L.). J. Res. ANGRAU. 41 (1) : 132-134.

Meena Kumari, K., K.V. Seetha Ramaiah, V. Satyanarayana and B. Sreekanth. 2011. Correlation and path co-efficient analysis in rice. The Andhra Agric. J. 58(4) : 434438.

Panse, V. G and P.V. Sukhatme. 1961. Statistical methods for agricultural workers. $2^{\text {nd }}$ Edition ICAR, New Delhi. Pp. 361. 
Panwar, L.L and Mashiat Ali, 2007 Correlation and path analysis of yield and yield components in transplanted rice. Oryza. 44 (2) : 115-120.

Parvathi, P.S., V. SatyanarayanaRao, M LalAhmed and P. Anilkumar. 2011. Correlation and path analysis of yield and quality attributes in rice. The Andhra Agric. J. 58 (3) : 310-314.

Prasad, G.S, M. Sujatha, L.V Subbarao and U. Chaitanya. 2013. Studies on variability, heritability and genetic advance for quantitative characters in rice (Oryza sativa L.). Annals of Bio. Res. 4 (6) : 372-375.

Satish, Y., K.V. Seetha Ramaiah, N Sree Rama Reddy and T.C.M. Naidu. 2003. Genetic variability, heritability and Genetic advance in scented rice (Oryza sativa L.). The Andhra Agricultural Journal. 50 (1\&2): 24-26.

Selvaraj Immanuel, C., Pothiraj Nagarajan, Thiyagarajan, K., Bharathi, M and Rabindran, R. 2011. Genetic parameters of variability, correlation and path-coefficient studies for grain yield and other yield attributes among rice blast disease resistant genotypes of rice (Oryza sativa L.). Afri. J. Biotech. 10 (17) : 3322-3334.

Seyoum, M., S. Alamesew and K. Bantte. 2012. Genetic variability, heritability correlation coefficient and path analysis for yield and yield related traits in upland rice (Oryza sativa L.). J. Plant Sci. 7 (1) : 13-22.

Singh, P.K., B.K. Dhakad, H.B Singh and A.K. Singh. 2012. Genetic variability and association analysis in rice (Oryza sativa L.) treated with trichoderma harzianum. Crop Res. 44 (1\&2) : 141-145.

Singh, R.K. and S.N. Kakar. 1977. Control on individual trait means during index selection. Proceedings of Third Congress. SABRAO (Canberra), 3 : 22-25.

Sivasubramanian, S and Madhavamenon, P. 1973. Combining ability in rice. Madras Agricultural Journal 60: 419-421.

Srinivas, T., P.V. Satyanarayana, P. Raghava reddy and Y. Suneetha. 2004. Studies on variability, character association and fertility restoration ability of elite indicatropical japonica derivatives of rice. Recent advances in rice based farming systems.

Sudharani, M., P. Raghavareddy, G. Hariprasad Reddy and Ch. Surendra Raju. 2013. Correlation and path coefficient analysis for yield and physiological attributes in rice (oryza sativa L.) hybrids under saline soil conditions. J. Res. ANGRAU 41(1) : 105 108.

Vanisree, S., K. Anjali, Ch. Damodar Raju, Ch. Surender Raju and M. Sreedhar. 2013. Variability, Heritability and association analysis in scented rice. J. Bio. Sci. 1 (4) : 347:352.

Wright, S. 1921. Correlation and causation. J. Agric. Res. 20 : 257-287.

Yadav, S.K., B.G. Suresh, Praveen Pandey and Binod Kumar. 2010. Assessment of genetic variability, correlation and path association in rice (Oryza sativa L.), J. Bio Sci. $18: 1-8$. 